\begin{tabular}{ll}
\hline & $\begin{array}{l}\text { Kastamonu Eğitim Dergisi } \\
\text { Kastamonu Education Journal }\end{array}$ \\
$\begin{array}{l}\text { Eylül 2019 Cilt:27 Sayı:5 } \\
\text { kefdergi.kastamonu.edu.tr }\end{array}$ & Başvuru Tarihi/Received: 02.11 .2018 \\
& Kabul Tarihi/Accepted: 11.01 .2019 \\
Dol: 10.24106/kefdergi.3415
\end{tabular}

\title{
Sınıf Öğretmenlerinin Perspektifinden Türkiye’de Etkili Çocuk Hakları Eğitimi: Problemler ve Öneriler
}

\section{Effective Children's Rights Education in Turkey from the Perspective of Classroom Teachers: Problems and Suggestions ${ }^{1}$}

\author{
Öz \\ Ayşe ÖZTÜRK², Muhammed EREN³, Büşra TOPÇU
}

Bu araştırmada, sınıf öğretmenlerinin perspektifinden Türkiye'de etkili çocuk hakları eğitimi (EÇHE) ile ilgili yaşanan problemlerin ve önerilerin incelenmesi amaçlanmıştı. Durum araştırması olarak desenlenen çalışmada, veriler odak grup görüşmesi ve yarı yapılandırılmış görüşme tekniğiyle toplanmıştır. Araştırmanın, çalışma grubunu amaçlı örnekleme yöntemlerinden maksimum çeşitlilik örnekleme yöntemiyle seçilmiş 15 sınıf öğretmeni oluşturmuştur. Araştırma verileri, içerik analizi yapılarak çözümlenmiştir. Araştırma sonucunda, EÇHE ile ilgili problemler; uygulama sürecinde gözlemlenen problemler, uygulama sürecinde karşılaşılan problemler ve ülke genelinde gözlemlenen problemler olmak üzere üç kategoride toplanmıştr. EÇHE için öneriler ise üç kategoride toplanmıştır. Bunlar; Milli Eğitim Bakanlığı için öneriler, öğretmen ve okul yönetimi için öneriler ve diğer önerilerdir. Araştırma, EÇHE ile ilgili problemleri ve önerileri uygulama sürecinin içindeki öğretmenlerin perspektifinden sunması açısından önem taşımaktadır.

Anahtar Kelimeler: çocuk hakları, çocuk hakları eğitimi, ilkokul eğitimi, sınıf öğretmenleri

\section{Abstract}

The objective of this study was to examine the problems experienced and suggestions regarding effective children's rights education (ECRE) in Turkey from the perspective of classroom teachers. In the study that was designed as a case study, the data were acquired by way of focus group interview and semi-structured interview methods. The study group was comprised of 15 classroom teachers selected via maximum variation sampling method which is among the purposive sampling methods. The study data were analyzed via content analysis. Problems related with ECRE were classified under three categories at the end of the study which are problems observed during application process, problems experienced during application process and problems observed in the country. Whereas the suggestions for ECRE were also classified in three different categories. These are; suggestions for the Ministry of Education, suggestions for teachers and school administration and other suggestions. The study is important since it puts forth problems and suggestions related with ECRE from the perspective of teachers who are part of the application process.

Keywords: children's rights, children's rights education, primary school education, classroom teachers

1. This study is the developed version of the paper which was presented as an oral presentation at the IVth International Eurasian Educational Research Congress, Denizli, Turkey.

2. Gaziantep Üniversitesi, Eğitim Fakültesi, Gaziantep, Türkiye; https://orcid.org/ 0000-0001-9279-1716

3. Milli Eğitim Bakanlığı, Gaziantep, Türkiye; https://orcid.org/0000-0003-2434-3027

4. Milli Eğitim Bakanlığı,, Şanlıurfa, Türkiye; https://orcid.org/0000-0002-1197-5976

Atff / Citation: Öztürk, A., Eren, M. \& Topçu, B. (2019). Effective children's rights education in turkey from the perspective of classroom teachers: problems and suggestions. Kastamonu Education Journal, 27(5), 2221-2232. doi:10.24106/kefdergi.3415 


\section{Extended Abstract}

Introduction: Children's rights aim to protect children from all kinds of neglect and abuse and provide the healthy development of children. Children's rights education is very important for realizing children's rights. Teachers are among the most important components of the children's rights education process. Teachers take on many tasks such as making arrangements, detecting and solving problems in order to teach children their rights and to ensure that they experience these rights. In this regard, the problems determined by the teachers who are the implementers of children's rights education and the solution suggestions they put forth are very important for children's rights education. Primary school education is one of the most important steps in the education of children's rights. Therefore, the problems and suggestions that classroom teachers have identified are very important for effective children's rights education (ECRE). In this direction, this study aimed to examine the problems related with ECRE in Turkey from the perspective of classroom teachers as well as solution suggestions.

Method: This study in which problems related with ECRE in Turkey along with suggestions for ECRE were examined from the perspective of classroom teachers has been patterned as a case study. The study group was determined via maximum variation sampling which is one of the purposive sampling methods and was comprised of 15 classroom teachers. The data were acquired by way of focus group interview and semi-structured interview methods. Semi-structured interview method conducted on 10 classroom teachers. Focus group interview carry out with five classroom teachers. Problems and Suggestions Interview Form in Effective Children's Rights Education was prepared and used in this study as data acquisition tool. The study data were analyzed via content analysis. Coding reliability was used in order to provide reliability in data analysis.

Results: The results acquired from the study have been presented under two different headings of problems related with ECRE and suggestions for ECRE. The problems defined for ECRE were classified under three categories as the problems observed during the application process, problems experienced during application process and problems observed in the country in general. The problems observed during the application process by the teachers have been defined as; Teachers considering it as a topic to teach, seeing psychological and physical violence as a type of discipline, having no course directly related with children's rights during primary school, lack of knowledge of teachers on children's rights education, lack of applied teaching, the fact that schools and classrooms are not locations where children's rights are put into effect, school and classroom not including it as part of the goals and lack of in-service training by the Ministry of Education. The problems experienced during application process have been defined as negative opinions of teachers on the necessity of children's rights education, lack of sufficient support from the school administration, not seeing children as right holders, lack of desire of the teachers to participate in the studies, physical structure of the school not in accordance with children's rights, low occupational belonging of teachers regarding children's rights education, problems related with the family factor. Another problem category related with ECRE in the study was the problems observed in the country in general. In this regard, issues related with ECRE have been defined as; lack of a national education policy on children's rights education, lack of children's rights and children's rights education courses during undergraduate education, lack of consciousness on children's rights in the society, shortcomings in application inspection, lack of sufficient support from non-governmental organizations and the lack of socially activating works by the media. The suggestions for ECRE have been classified under three categories as suggestions for $\mathrm{MOE}$, suggestions for teachers and school administration and other suggestions. Suggestions for MOE have been defined as preparation of programs for children's rights education, provision of in-service trainings on children's rights education to the teachers and setting knowledge on children's rights and its education as one of the fundamental criteria for teacher assignment along with developing an inspection mechanism for children's rights education. The suggestions for ECRE for teachers and school administration have been defined as making children learn their rights through application, establishing a school and classroom culture based on children's rights and developing projects in which children take part in the decision making and planning stages. In the other suggestions category, the emphasis has been on raising the awareness of families and the society for ECRE, organizing teacher education programs and establishing a national education policy. In this scope, suggestions have been made for raising the awareness of families through media and non-governmental organizations, the Ministry of Family and Social Policies carrying out activities for raising the awareness of families, including courses on children's rights education in teacher training and preparing a national education policy.

Suggestions: When the study results are evaluated in general, it can be put forth that various problems have been defined for ECRE in the application process and in the country (Turkey) in general and that various suggestions have been made in this regard. According to the results of the study, it is suggested that preparing programs for children's rights education in primary school and preparing a national education policy, carrying out activities for raising the awareness of families and providing in-service trainings on children's rights education to the teachers. Also, it is recommended that setting knowledge on children's rights and its education as one of the fundamental criteria for teacher assignment and developing projects in which children take part in the decision making and planning stages at schools.

| Kastamonu Eğitim Dergisi, 27(5), 2019| 


\section{Introduction}

Children's rights is a universal concept that all children in the world are entitled to from birth either by law or ethic that provides children rights such as education, health, accommodation and protection from physical, psychological or sexual abuse (Erbay, 2016). These rights aim to protect children, provide them the values and standard of life they deserve and to ensure that they are raised as healthy individuals (Akyüz, 2016). Putting the children's rights into practice requires and effective children's rights education (ECRE). Children's rights education is important for providing children with skills of democratic citizenship, forming awareness related with their rights, providing them with skills for protecting and respecting the rights of others while protecting them from abuse and neglect, enabling them to participate in social life in an active manner, develop their self-confidence, acquire educational rights and be raised as healthy individuals (Flowers et al., 2009; Özdemir Uluç, 2008). In addition, a more in-depth understanding of the rights and social responsibility has many benefits such as the provision of an advanced school environment and participation, increase of success in addition to many other social and educational benefits (Covell, Howe, \& Polegate, 2011). In this regard, there is an increasing interest towards the education of children on fundamental rights and responsibilities as part of the school programs (Howe \& Covell, 2010). Children's rights education means the teaching of rights to children by forming respected and exemplary education environments based on the acknowledgement that all children are equal (Kapai, Bacon-Shone, Walsh, \& Wong, 2014) and that they are all right owners (Howe \& Covell, 2007). This education process requires the learning of these rights and responsibilities by experience and the establishment of a school culture based on children's rights (Lansdown, Jimerson, \& Shahroozi, 2014). Teachers are among the most important components of the children's rights education process. Teachers take on many tasks such as making arrangements, detecting and solving problems in order to teach children their rights and to ensure that they experience these rights. In this regard, the problems determined by the teachers who are the implementers of children's rights education and the solution suggestions they put forth are very important for children's rights education. When it is considered that formal education for children's rights is carried out at the primary school within the scope of various courses and that various activities are carried out for the participation right of children such as school student council or the participation of students in social activities commission, it can be stated that classroom teachers play a significant role in this process. In this regard, it can be stated that the data that will be acquired from classroom teachers shall put forth comprehensive and in-depth information for the problems faced during the ECRE process as well as solution suggestions. The references that could be reached via a literature survey were limited and no study was found which focuses on the problems experienced during effective children's rights education or the solution suggestions for such problems. When these studies are examined, it was observed that these studies focused on different issues related to children's rights and children's rights education. In this direction Çetinkaya (1998), Salman Osmanoğlu (2007), Kop and Tuncel (2010), Neslitürk and Ersoy (2007) investigated the view of teachers, preservice teachers and students to childrens rights. In their study, Öztürk and Özdemir Doğan (2017) were examinated the understanding and applications with regard to ECRE of teachers expert in children's rights education. In the other studies, Dinç (2015), Yurtsever Kılıçgün (2015) evaluated the attitudes and understanding of parents related children's rights. Nayır and Karaman-Kepenekçi (2011), Karaman- Kepenekçi and Aslan (2011), Karaman-Kepenekçi (2010) and Öztürk, Topçu and Eren (2017) in their examined the textbooks in terms of children's rights. With the historical analysis, Öztürk (2017), examinated the life sciences curricula in Turkey in terms of children's participation rights. In their studies, Uçuş (2013) and Torun and Duman (2014) focused developing awareness and attitude related children's rights. Doğan, Torun and Akgün (2014) examined the attitudes of preservice pre-school teachers towards children's rights in terms of various variables. Polat, Alkan Ersoy and Toran (2017) in their study developed child participation awareness scale. Öztürk and Doğanay (2017a) in their studies developed a scale for the attitude towards children's rights education. The other study, Öztürk and Doğanay (2017b) developed children's rights-based school scale. In their study, Yurtsever Kilıçgün and Oktay (2011) focused on development and standardization of parental attitude scale for children's rights. Another study, Karaman-Kepenekçi (2006) investigated university students' attitudes towards children's rights. Kılıç and Öztürk (2018), in their research aimed to explore to children's right to participation level in a primary school which is highly qualified in terms of children's rights. Tozduman Yaralı and Güngör Aytar (2017) investigated children's rights to participation in preschool classes according to children's and teachers' views. It is observed that studies on children's rights generally focus on the determination of teacher, preservice teachers and student opinions, examination of the understanding and applications with regard to ECRE of teachers expert in children's rights education, evaluation of the attitudes of parents, analysis of course material and curriculum, examination of the children's participation rights, and scale development for children's rights.

It is thought that carrying out such a study on classroom teachers shall make a significant contribution for filling the gap in the related literature and shall be an important reference for futures studies that will be carried out on ECRE. 
In accordance with the aforementioned justifications, the objective of this study was to examine the problems related with ECRE in Turkey from the perspective of classroom teachers as well as solution suggestions.

\section{Method}

\section{Research Model}

This study in which problems related with ECRE in Turkey along with suggestions for ECRE were examined from the perspective of classroom teachers has been patterned as a case study (Patton, 2002). Case study is a qualitative research method in which the researcher examines one or more cases in detail (Christensen, Johnson, \& Turner, 2011) thus enabling the acquisition of a holistic and significant characteristics regarding real life cases (Yin, 2009). The objective of this study was to examine in detail the problems related with ECRE at the primary school level from the perspective of classroom teachers as well as their solution suggestions and to develop a holistic understanding as a result. Focus group interview and semi-structured interview methods from among the data acquisition methods were used in the study.

\section{Study Group of the Research}

The study group was determined via maximum variation sampling which is one of the purposive sampling methods (Patton, 2002) and was comprised of 15 classroom teachers. Semi-structured interview method conducted on 10 classroom teachers. Two of the teachers in the study group were experienced, two were inexperienced, two were experts on children's rights education, two had master's degrees and two had different undergraduate degrees but all were working as classroom teachers. Inexperienced, experienced and expert teachers were determined in accordance with the criteria in the related literature (Korevaar \& Bergen, 1992; Moallem, 1994; Öztürk \& Özdemir Doğan, 2017; Schempp, Tan, Manross, \& Fincher, 1998). In this regard, the characteristics of the classroom teachers that make up the study group were as follows: Both of the inexperienced teachers have an experience of five months. Of the two experienced teachers who have graduated from classroom teaching department, the female teacher had an experience of 14 years, whereas the male teacher had an experience of 9 years. One of the expert teachers has completed a graduate degree thesis on effective children's education, has an academic publication, has worked in two projects and has an experience of 7 years. Whereas the other is currently continuing a thesis study on the formation of awareness on children's rights and has two academic publications. The number of attended projects is 3 and has an experience of 4 years. One of these teachers was male and the other was female. Teachers with a graduate degree level of education have experiences of 9 and 14 years with a master's degree on classroom teaching. Both of these teachers were male. Of the teachers with different undergraduate degrees, one was a veterinary faculty graduate whereas the other was a biology department graduate. Both these teachers were female with experiences of 21 and 19 years.

Focus group interview carry out with five classroom teachers. One of these teachers was experienced, one was inexperienced, one was experts on children's rights education, one had master's degree and one had different undergraduate degree but was working as classroom teacher. From these, inexperienced teacher had an experience of four months and was female. The experienced teachers who have graduated from classroom teaching department, the male teacher had an experience of 18 years. The expert teacher has completed a graduate degree thesis on effective children's education, has four academic publications, has worked in one project and has an experience of 16 years. The teacher was male. Teacher with a graduate degree level of education have experiences of 6 years with a master's degree on classroom teaching. The teacher was female. The teacher with different undergraduate degree was female and had an experience of 20 years.

\section{Data Collection Tool}

Problems and Suggestions Interview Form in Effective Children's Rights Education was prepared and used in this study as data acquisition tool. Open ended questions were prepared in the Interview Form in Effective Children's Rights Education for the problem definitions and suggestions on ECRE. The prepared questions were presented to expert opinion, two classroom teachers carried out a pilot application after which the form reached its final state. The following questions have been included in the Interview Form in Effective Children's Rights Education:

- Are there any problems you met or observed during the application process for the effective actualization of children's rights education? If you do, could you please explain them?

- Are there any problems you observed regarding effective children's rights education in the country (Turkey) in general? If there are, could you please explain them?

- Do you have suggestions on how children's rights education can be carried out effectively? If you do, could you please explain them? -What are your suggestions for the direct application process such as school and classroom? -What are your suggestions for an effective children's rights education in the country (Turkey) in general?

| Kastamonu Eğitim Dergisi, 27(5), 2019| 


\section{Data Collection}

Separate semi-structured interviews were carried out with the teachers comprising the study group of semi-structured interview. The semi-structured interview process was recorded using a camera in order to prevent data loss. The interviews lasted about 34-47 minutes. For focus group interview, a two-person research team was formed for moderating and recording, a camera and a voice recorder were prepared to record the process. Moderator was experienced related focus group interviewer and children's rights education. During the implementation process, firstly the process of acquaintance was made and information was given about implementation process. In this process, the moderator was careful not to express his views and not to be a controlling for participants' views. All participants were provided to express their opinions. During the implementation process, 1 hour 13 minutes recorded.

\section{Data Analysis}

During the data analysis process, first the camera records were transformed into a written data set. The prepared data set was analyzed via content analysis. Open and selective coding process was followed during data analysis (Strauss \& Corbin, 1990). The prepared codes were classified in different categories according to similarities and differences. In this regard, three categories were reached related with problems defined for ECRE. These categories were defined as the problems observed during the application process, problems experienced during application and problems observed in the country in general. At the same time, three categories have been defined related with the suggestions for ECRE. These categories were defined as suggestions for the Ministry of Education, suggestions for teachers and school administration and other suggestions.

\section{Reliability and Validity Studies of Data Analysis}

In order to prevent data loss, all interview processes were recorded. The study groups, the research process and data analysis process were explained in detail. Descriptive information is given to make the clear how the inferences have been reached. Coding reliability was used in order to provide reliability in data analysis. The coding performed by this master coder was compared with the codes of the researchers. Consensus was calculated as .97 (Miles \& Huberman, 1994). Codes with a difference of opinions were discussed and a consensus was reached.

\section{Findings}

The results acquired from the study have been presented under two different headings of "Problems Related with ECRE" and "Suggestions for ECRE".

\section{Problems Related with ECRE}

Findings on the problems related with ECRE defined by the classroom teachers have been presented in Table 1.

\section{Table 1. Problems Defined for ECRE}

\begin{tabular}{|c|c|}
\hline Categories & Codes \\
\hline$\stackrel{1}{\stackrel{1}{\widetilde{U}}}$ & Teachers considering it as a topic to teach \\
\hline$\frac{\frac{.}{2}}{\frac{2}{0}}$ & No course directly related with children's rights during primary school \\
\hline 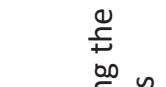 & Lack of knowledge of teachers on children's rights education \\
\hline .气 & Lack of applied teaching \\
\hline $\begin{array}{ll}0 & \overline{2} \\
\sum_{d}^{2} & \frac{1}{0}\end{array}$ & The fact that schools and classrooms are not locations where children's rights are put into effect \\
\hline $\begin{array}{l}n \\
0 \\
0\end{array}$ & School and classroom not including it as part of the goals \\
\hline$\frac{\frac{c}{0}}{\frac{0}{0}}$ & Lack of in service training by the Ministry of Education \\
\hline $\bar{a}$ & Accepting psychological and physical violence as a form of discipline \\
\hline
\end{tabular}




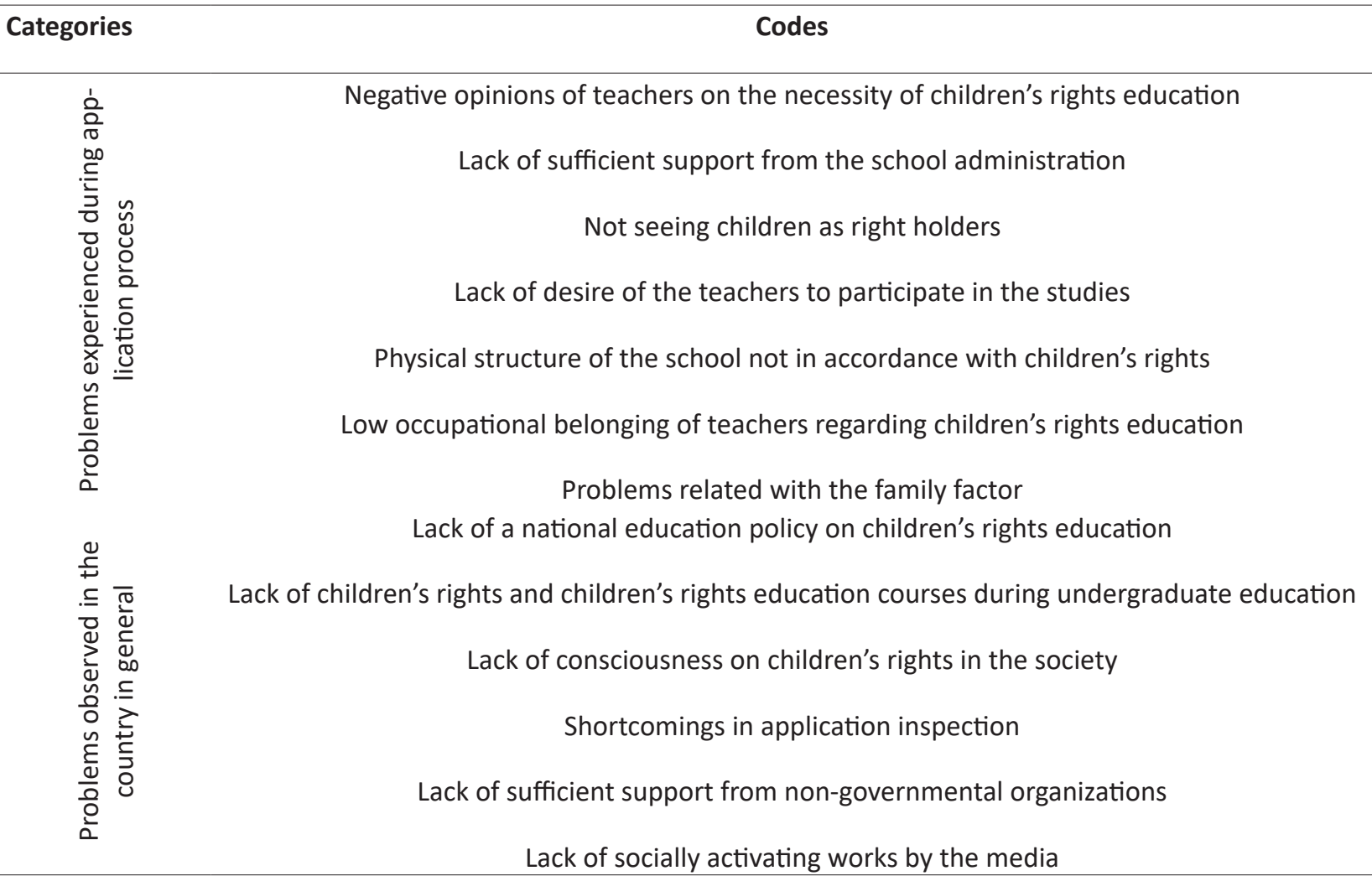

When Table 1 is examined, it is observed that the problems defined for ECRE can be classified under three categories as the problems observed during the application process, problems experienced during application process and problems observed in the country in general. Of these, the category of problems observed during the application process covers the problems related with ECRE observed by the teachers during the education process. The problems observed by the teachers have been defined as; Teachers considering it as a topic to teach, seeing psychological and physical violence as a type of discipline, having no course directly related with children's rights during primary school, lack of knowledge of teachers on children's rights education, lack of applied teaching, the fact that schools and classrooms are not locations where children's rights are put into effect, school and classroom not including it as part of the goals and lack of in-service training by the Ministry of Education. Regarding this issue, one of the teachers has stated:

"...actually teachers see children's rights as a course topic that should be taught, because it is considered like that in social studies class, information is not given to the child as to how he/she will use it, the child does not even know that he/she has rights... schools are not places where children may learn and use their rights, children are only told their responsibilities; do your homework, be at the classroom on time, do not run in the corridors... indeed, classrooms are not places where children feel that they have rights..." (T4)

Another teacher stated the following:

"...children are subject to violence under the name of nurture. Physical and psychological violence are considered as a type of discipline, how can the child live his/her own rights in such an environment, neither the school nor the classroom have such goals in general, their only goal is the success of the student; also, as far as I can observe, teachers have no idea on children's rights or education, nothing, and I was also not aware of this, I learned about them during my graduate study, it is where l learned that these are drawbacks, the ministry should provide in-service trainings but they do not..." (T5)

When the explanations are examined, it can be stated that the problems related with ECRE defined by the teachers have been shaped around content arrangement, lack of knowledge of teachers, lack of school and classroom culture and supporting education.

The category of problems experienced during application process is comprised of problems that teachers face during their own applications. In this scope, the teachers have expressed the problems they faced during their own application process as; Negative opinions of teachers on the necessity of children's rights education, lack of sufficient support from the school administration, not seeing children as right holders, lack of desire of the teachers to participate in the studies, physical structure of the school not in accordance with children's rights, low occupational belonging of teachers regarding children's rights education, problems related with the family factor. The teachers have put forth 
within the framework of the problems related with the family factor that families do not have an awareness of children's rights and its importance, that they do not provide the required support and that the family environment is not suited to children's rights. One of the teachers has expressed this in the following way:

"...for example, the child is subject to violence in the family, his/her opinions are not given any importance. The child also does not have any say. No matter how much we tell this child that he/she has the right to participate and that he/she should voice his/her opinions without hesitation, the child cannot do that. There are inconsistencies between the school and family environments. The family environment of the child is not convenient for him/her to experience his/her rights. The parents are also not very willing to take a step in that direction..." (T1)

The teachers also stated in the study that they experience various problems with the school administration and their colleagues. In this regard, they have put forth that their colleagues do not provide the required support because they do not believe in the necessity of children's rights, that they are unwilling to participate in the studies and that they do not consider it as part of their occupation. One of the teachers told the following about this issue:

"...one of the fundamental problems that I experience is related with my friends; many of my colleagues think that children's rights education is unnecessary, they tell me that I am putting my efforts in vain, they tell me that we are required to make the children be successful not teach them their rights and the related laws..." (T6).

In the study, some of the problems experienced have been put forth to be related with the physical structure and administration of the schools. In this regard, the teachers have emphasized that the school administration does not provide sufficient support while also stating the insufficiency of the physical structure of the school. One of the teachers has put forth the lack of support from the school administration as follows: "... my principal complains about me, he does not think well of such studies... he says that the children know their rights more than the lessons and that they will soon abuse it..." (T4). Whereas another teacher put forth the insufficiency of the physical structure of the school as follows:

"...for one, our school structure is not suited to this... the four storey building is not suited to the children, they keep pushing each other on the stairs... the garden is concrete, they get injured when they fall...there is no area designed for play..." (T2).

It can be stated that the problems experienced by the teachers during application are centered on the lack of attitude of the school administration and teachers, family factor and the physical structure of the school.

Another problem category related with ECRE in the study was the problems observed in the country in general. In this regard, issues related with ECRE have been defined as; lack of a national education policy on children's rights education, lack of children's rights and children's rights education courses during undergraduate education, lack of consciousness on children's rights in the society, shortcomings in application inspection, lack of sufficient support from non-governmental organizations and the lack of socially activating works by the media. Of these, the teachers indicated social structure as one of the fundamental reasons for the failure in children's rights education within the scope of the lack of awareness on children's rights. One of the teachers expressed this as follows:

"... regarding why the children's rights activities in our country are not successful, first of all there is a general lack of knowledge... a social change is a must. There is no stable children's rights idea in our country... there is a lack of consciousness on this issue... The perspective and perception of the society regarding children's rights should be changed. Otherwise, all efforts by the Ministry of Education will be in vain..." (T7).

In addition, the inspection mechanism along with insufficiencies regarding the support by non-governmental organizations and the media have also been defined as problems. One of the teachers put forth this issue as follows:

"...inspection mechanisms of the ministry for children's rights education in our country are lacking... what do you think are the two important structures that can develop social awareness? The answer is of course non-governmental organizations and media, but they do not provide the required support in our country... they do not take responsibility..." (T15).

In addition, lack of a national education policy on children's rights education and the lack of children's rights and children's rights education courses during undergraduate education have been determined as significant problems by the teachers. In this regard, it can be stated that the problems observed in the country in general are focused more on lack of a national education policy, lack of national consciousness and insufficiencies in undergraduate education. 


\section{Suggestions for ECRE}

In the study, classroom teachers made suggestions regarding what can be done for ECRE. Table 2 shows the suggestions put forth for ECRE.

Table 2. Suggestions for ECRE

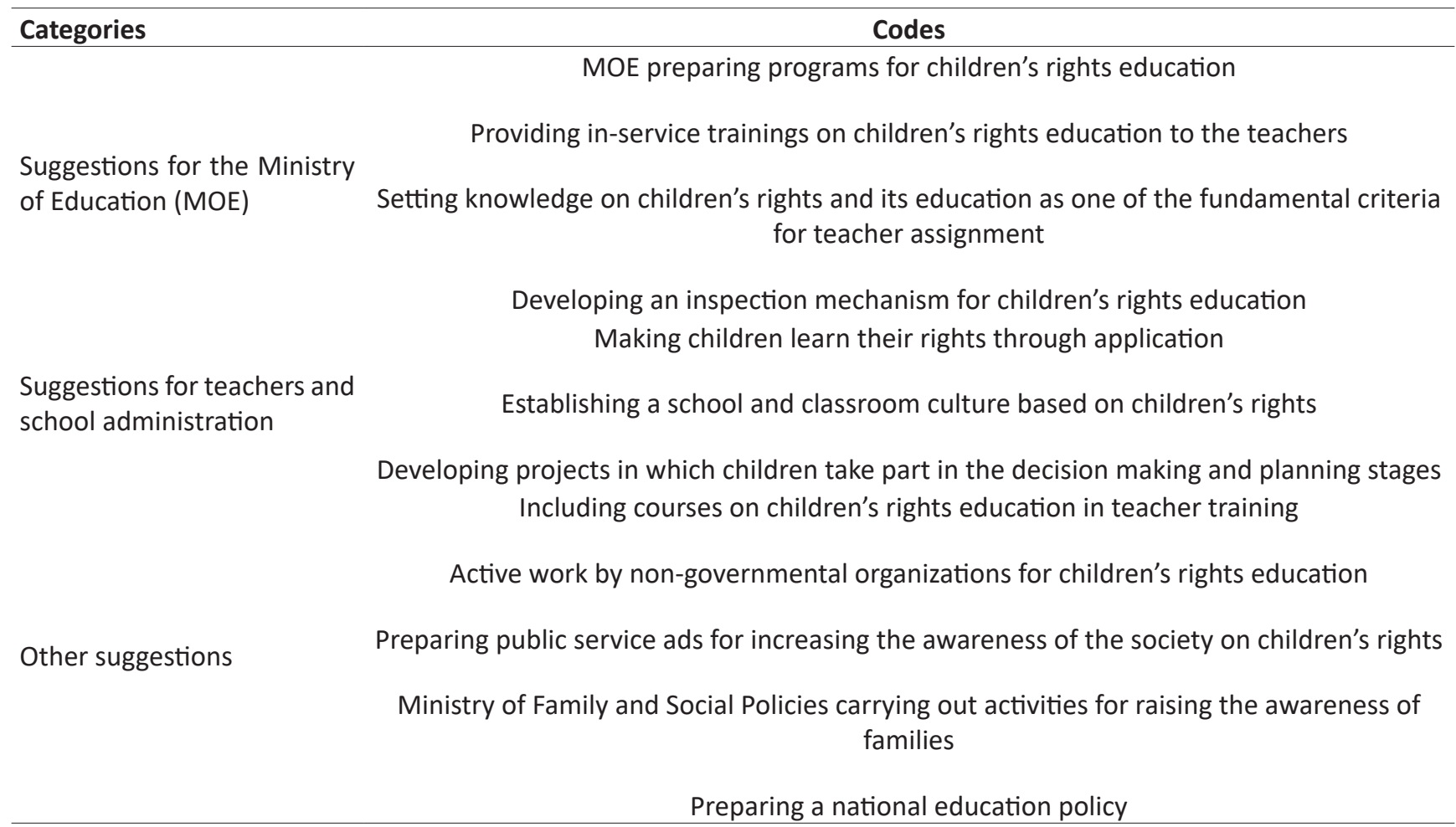

When Table 2 is examined, it is observed that the suggestions for ECRE have been classified under three categories as suggestions for $\mathrm{MOE}$, suggestions for teachers and school administration and other suggestions. Of these, the category of suggestions for the Ministry of National Education includes opinions put forth by classroom teachers regarding what can be done by MOE for ECRE. In this regard, the classroom teachers who participated in the study emphasized the preparation of programs for children's rights education, provision of in-service trainings on children's rights education to the teachers and setting knowledge on children's rights and its education as one of the fundamental criteria for teacher assignment along with developing an inspection mechanism for children's rights education. One of the teachers put forth the suggestions for the preparation of in-service trainings and education programs as follows:

"...as I stated while listing the problems, we as teachers do not have sufficient knowledge and skills on children's rights education. Therefore, it is not possible to teach these to the kids as well. Therefore, it is very important that MOE provides us with in-service trainings, on the other hand, a separate program should also be prepared for children's rights; only in this way can we teach the children their rights and the importance of children's rights education can be understood in this manner..." (T1)

One of the teachers put forth the following regarding the suggestion that children's rights education should be included as one of the fundamental criteria for teacher assignment:

"...one of the most important regulations that can be carried out by MOE will be setting knowledge on children's rights and its education as one of the fundamental criteria for teacher assignment. The teacher inflicts violence on the student, disrupts his/her psychology through verbal abuse or the child realizes bad experiences such as abuse but cannot do anything about it... Teachers who should help the students to experience their rights or to teach them their rights violate these rights without being aware of it... therefore, teacher candidates should have knowledge on how to teach children their rights before they become teachers..." (T5)

When the explanation is examined, it can be observed that the teacher attracts attention to carrying out the required controls as to whether the teacher candidates have received the required capability for respecting the rights of children, protecting them and teaching them.

In the category of suggestions for ECRE for teachers and school administration, the emphasis has been on what should be done by the teacher and school administration in application. In this scope, they have emphasized making children learn 
their rights through application, establishing a school and classroom culture based on children's rights and developing projects in which children take part in the decision making and planning stages. One of the teachers expressed this as follows:

"...it is one of the biggest mistakes to teach it as course content, it should be taught via application and it is very important to teach their rights through experience, the publications I have examined on this issue emphasize this a great deal... establishing a school and classroom culture is another important issue, our schools and classrooms should be places where children live their rights, that is school and classroom culture should be based on children's rights... projects should be developed which enable children to take part. However, children should be directly included in both the planning and decision making stages..." (T8)

In the other suggestions category, the emphasis has been on raising the awareness of families and the society for ECRE, organizing teacher education programs and establishing a national education policy. In this scope, suggestions have been made for raising the awareness of families through media and non-governmental organizations, the Ministry of Family and Social Policies carrying out activities for raising the awareness of families, including courses on children's rights education in teacher training and preparing a national education policy. One of the teachers has expressed the following for the suggestion of preparing a national education policy:

"...children's rights education will be effective only if a national education policy is developed. Otherwise, it will always be lacking and will end up as a failure. For example, MOE prepares a program but if the teacher does not take the required skills during his/her education, the program application will be ineffective, or if the family and society dimensions are lacking, the education at school will be a failure... a national education policy that will bring forth a holistic understanding is necessary..." (T7)

Whereas another teacher made the following comments for raising the awareness of the society, non-governmental organizations, preparation of public service ads and the preparation of a teacher education program:

"...social movement is required, otherwise children who are taught at schools cannot find the value they deserve in the society, they cannot live their rights... public service ads should be effective for reaching out to the public and raising their awareness... non-governmental organizations should work more actively and should educate the public on children's rights... actually we had talked about this before but I want to state it as a suggestion as well, courses on children's rights education should be included in the curriculum of undergraduate programs, teacher candidates should be taught as to what kind of a developmental psychology they will use during their courses in addition to the rights of children and how they can teach these rights..." (T9)

Whereas another teacher indicated the following suggestion for the ministry of family and social policies:

"the family is very important, the child's home is the first place where they will experience their rights and learn about them... we are trying to make the children speak out in schools but at homes the families either make them silent or inflict violence on them and the family should take part in social policies, works should be carried out for raising the awareness of families..." (T10).

When the explanations are evaluated in general, it can be stated that the teachers emphasized different contexts such as the carrying out of certain arrangements by the Ministry of National Education for ECRE, preparation of a national education policy, raising the awareness of the society and the family as well as teacher education.

\section{Discussion and Results}

At the end of the study, various problems were determined with regard to the effective actualization of children's rights in Turkey and suggestions were presented. The fact that children cannot be taught their rights in practice, that children's rights education are not among the goals of schools and classrooms and that the physical structure of the schools are not suited have been listed among the problems in the study. In parallel to these problems, applied teaching of their rights to the children and the development of a school and classroom culture were set forth as suggestions. Related literature attracts attention to the importance of making the children learn their rights through practice and the development of a school culture in order to attain an effective children's rights education (Howe \& Covell, 2007; Landsdown et al., 2014). On the other hand, lack of knowledge of teachers on children's rights and its education is a significant factor in the ineffective application of the charter (Robson, 2016) which was also put forth among the problems in this study. Howe and Covell (2007) also indicate that lack of knowledge of teachers on children's rights is also effective in their unwillingness to teach children their rights and indeed that teachers see children's rights as a threat to classroom management. While this points out to the necessity of carrying out in-service trainings to teachers on children's rights education, it can also be stated that it supports the suggestion of participants for ECRE. In addition, it has also been determined that the negative attitude of teachers in the study on children's rights education has been determined among problems defined for ECRE. When the effects of the attitudes of teachers on their behavior are 
considered, it can be stated that the attitude problem is a significant determination.

Among the problems listed by the teachers in the study, the fact that there is not a separate course on children's rights education in Turkey and in relation the fact that children's rights is not perceived as a topic to be taught have also been included. In addition, they also made a suggestion to MOE for the preparation of programs. This can be stated to be effective in raising an awareness required for the importance of children's rights education to teachers. On the other hand, it is stated in the relevant literature that the most important area of action is teacher education programs (Jerome, Emerson, Lundy, \& Orr, 2015). In this regard, attention is drawn to placing courses on children's rights education in teacher education programs (Shumba, 2003). Similarly, this deficiency was emphasized in this study as well and suggestions were made for placing courses on children's rights education in teacher education programs in Turkey. Regarding the teachers, it can also be stated that the suggestion for setting knowledge on children's rights and its education as one of the fundamental criteria for teacher assignment, making classrooms in accordance with children's rights, teaching children their rights through experience, raising awareness against child abuse and neglect will be beneficial in the long term for raising children into citizens who have embraced democratic values and who respect human rights. Another issue that was emphasized in the study for ECRE has been the family. Family is among the most important factors for carrying out an effective children's rights education and enabling children to experience their rights. Indeed, UN puts forth various responsibilities to the families in this regard in CRC (Hodgkin \& Newell, 1998). This puts forth the necessity for the families to be informed on children's rights. Attention was drawn to the necessity of family education in this study while pointing out the family related issues regarding ECHE.

National education policy was another factor that was included among the problems and suggestions for ECRE in the study. Education policy plays an important role in determining how the education system of the country will be shaped and what will be done for education (Sağlam, Özüdoğru, \& Çıray, 2011). In this regard, it can be stated that a national education policy is a requirement for a radical change for children's rights education. In addition, governments generally do not develop their education policies and regulations from the perspective of children (Lansdown et al., 2014). Whereas the teachers who participated in the study indicated the lack of a national education policy as a deficiency, they have put forth that the development of a national education policy for children's rights education is a must for developing a holistic approach in cooperation with MOE. Another issue that was emphasized for ECRE in the study was non-governmental organizations. Non-governmental organizations play an important role in the development of a human rights culture (Flowers et al., 2009; Sajan, 2010) and these institutions carry out various works such as preparing education programs and material for human rights education or raising professionals (Flowers et al., 2009). When it is considered that children's rights is a special field of human rights (Shumba, 2003), it can be stated that active work by way of non-governmental organizations is important for ECRE. It can also be put forth that the suggestion for non-governmental organizations to work more actively is also supported in this manner.

Another issue pointed out as part of the problems related with ECRE by the participating teachers was the lack of works by the media does to incite a social movement in addition to a lack of social consciousness. Works should be carried out for creating a social awareness and for raising awareness for children's rights in order to ensure that children receive the value they deserve and that their rights are respected. When the effects of media on the public through education, informing and molding public opinion are considered (Genç \& Güner, 2016), it can be stated that media is one of the most effective factors for inciting a social movement and for raising awareness. In this regard, it can also be stated that attracting attention to the media is an important aspect for ECRE.

When the study results are evaluated in general, it can be put forth that various problems have been defined for ECRE in the application process and in the country in general and that various suggestions have been made in this regard.

\section{Suggestions}

According to the results of the research, it is suggested that preparing programs for children's rights education in primary school and preparing a national education policy, carrying out activities for raising the awareness of families and providing in-service trainings on children's rights education to the teachers. Also, it is recommended that setting knowledge on children's rights and its education as one of the fundamental criteria for teacher assignment and developing projects in which children take part in the decision making and planning stages at schools.

\section{References}

Akyüz, E. (2016). Çocuk hukuku: çocukların hakları ve korunması. Ankara: Pegem Akademi. 
Christensen, L. B., Johnson, R. B., \& Turner, L. A. (2011). Research methods, design, and analysis. Boston, MA: Allyn \& Bacon/ Pearson.

Covell, K., Howe, R. B., \& Polegato, J. L. (2011). Children's human rights education as a counter to social disadvantage: A case study from England. Educational Research, 53(2), 193-206.

Çetinkaya, N. (1998). Öğretmenlerin ve öğrencilerin çocuk haklarına bakışının değerlendirilmesi (Yayımlanmamış yüksek lisans tezi). Marmara Üniversitesi, İstanbul.

Dinç, B. (2015). Okul öncesi eğitim kurumuna devam eden çocukların ebeveynlerinin çocuk hakları eğitimi konusundaki görüşleri. Eğitimde Nitel Araşttrmalar Dergisi, 3(1), 7-25.

Doğan, Y., Torun, F., \& Akgün, İ. H. (2014). Okul öncesi öğretmen adaylarının çocuk haklarına ilişkin tutumlarının çeşitli değişkenlere göre incelenmesi. International Journal of Human Sciences, 11(2), 503-516.

Erbay, E. (2016). Çocuk Katılımı. Ankara: Nobel Yayınevi

Flowers, N., Brederode-Santos, M. E., Claeys, J., Fazah, R., Schneider, A., \& Szelényi, Z. (2009). Compass: Manual on human rights education for children. Budapeste: Council of Europe Retrieved from http://www.eycb.coe.int/compasito/pdf/Compasito\%20EN.pdf

Genç, S. Z., \& Güner, F. (2016). Çocuk hakları bağlamında medyaya ilişkin aile görüşleri (Çanakkale ili örneği). Uşak Üniversitesi Sosyal Bilimler Dergisi, 9(26), 1-23.

Hodgkin, R., \& Newell, P. (1998). Implementation handbook for the Convention on the Rights of the Child. New York: UNICEF.

Howe, R.B, \& Cowell, K. (2007). Empowering children: children's rights education as a pathway to citizenship. Toronto Canada: University of Toronto Press

Howe, R.B., \& Covell, K. (2010). Miseducating children about their rights. Education, Citizenship and Social Justice, 5(2), 91-102

Jerome, L., Emerson, L., Lundy, L., \& Orr, K. (2015). Teaching and learning about child rights: A study of implementation in 26 countries. Geneva: UNICEF

Kapai, P., Bacon-Shone, J., Walsh, S., \& Wong, F. (2014). Children rights education: International legal framework and state party obligation. Hong Kong Committee for UNICEF. Retrieved from http://www.law.hku.hk/ccpl/research/KapaiCREUNICEFExecutiveSummary.pdf

Karaman-Kepenekci, Y. (2006). A study of university students' attitudes towards children's rights in Turkey. The International Journal of Children's Rights, 14, 307-319.

Karaman-Kepenekçi, Y. (2010). Children's social rights in social studies textbooks in Turkish elementary education. Procedia Social and Behavioral Sciences, 2(2), 576-581.

Karaman-Kepenekci, Y., \& Aslan, C. (2011). Okul öncesi döneme seslenen kitaplarda çocuk hakları. Ankara: Ankara Üniversitesi Basımevi.

Kılıç, A., \& Öztürk, A. (2018). An analysis of children's right to participation at primary schools in Turkey: A case study. Qualitative Research in Education, 7(3), 265-303.

Kop,Y., \& Tuncel, G. (2010). Sosyal bilgiler öğretmenlerinin çocuk haklarını algılamaları. Eğitimde Kuram ve Uygulama Dergisi, 6(1), 106-124

Korevaar, G. A. G., \& Bergen, T. C. M. (1992). Inexperienced and experienced teachers' differences in reacting and attributing to problematic classroom situations. Paper presented at the Annual Meeting of the American Educational Research Association, San Francisco.

Lansdown, G., Jimerson, S.R., \& Shahroozi, R. (2014). Children's rights and school psychology: children's right to participation. Journal of School Psychology, 52(1), 3-12.

Merey, Z. (2012). Illköğretim sosyal bilgiler öğretiminde vatandaşlık ve insan hakları eğitimi. Ankara: Pegem Akademi

Miles, M. B., \& Huberman, A. M. (1994). Qualitative data analysis: An expanded sourcebook (2nd ed.). Thousand Oaks and London: Sage Publication

Moallem, M. (1994). An experienced teacher's model of thinking and teaching: An ethnographic study on teacher cognition. Paper presented at the Annual Meeting of the American Educational Research Association, New Orleans, LA.

Nayır, F., \& Karaman Kepenekci, Y. (2011). Children's participation rights in elementary schools' Turkish textbooks elementary. ilköğretim Online, 10(1), 160-168

Neslitürk, S., \& Ersoy, F. (2007). Okul öncesi öğretmen adaylarının çocuk haklarının öğretimine ilişkin görüşleri. Eğitimde Kuram ve Uygulama, 3(2), 245-257.

Özdemir Uluç, F. (2008). ilköğretim programında insan hakları (Yayınlanmamış doktora tezi). Ankara Üniversitesi, Ankara.

Öztürk, A. (2017). Türkiye'de hayat bilgisi dersi öğretim programlarında çocukların katılım hakkı: tarihsel bir analiz. Adıyaman Üniversitesi Sosyal Bilimler Enstitüsü Dergisi, 27, 864-890. DOI: 10.14520/adyusbd.329894

Öztürk A., \& Doğanay, A. (2017a). Development of a scale for the attitude towards children's rights education. Educational Process International Journal, 6(3), 26-41. 
Öztürk, A., \& Doğanay, A. (2017b). Çocuk hakları temelli okul öçeğinin geliştirilmesi. Trakya Üniversitesi Sosyal Bilimler Dergisi, 19(1), 41-58.

Öztürk, A., \& Özdemir Doğan, G. (2017). Effective children's rights education from the perspectives of expert teachers in children's rights education: A Turkish sample. Journal of Education and Learning, 6(4), 303-314.

Öztürk, A., Topçu, B., \& Eren, M. (2017). 4. Sınıf insan hakları, yurttaşlık ve demokrasi ders kitabının çocukların katılım hakkı bağlamında incelenmesi. IV. International Eurasian Educational Research Congress, Denizli

Patton, M. Q. (2002). Qualitative research \& evaluation methods. Thousand Oaks, CA: Sage.

Polat, B. D., Alkan Ersoy, Ö., \& Toran, M. (2017). Çocuk katılımı farkındalık ölçeği (ÇKFÖ): Ölçek geliştirme, güvenirlik ve geçerlik çalışması. Erken Çocukluk Çalışmaları Dergisi, 1(2), 186-215

Robson, J. (2016). Early years teachers and young children's rights: the need for critical dialogue. Research in Teacher Education, 6(1),6-11.

Sağlam, M., Özüdoğru, F., \& Çıray, F. (2011). Avrupa Birliği eğitim politikaları ve Türk eğitim sistemine etkileri. Yüzüncü Yıl Üniversitesi Eğitim Fakültesi Dergisi, 8(1), 87-109.

Sajan, K. S. (2010). Human rights education ways and means (pp.13). Online Submission, (ERIC Document Reproduction Service No. ED509341)

Salman Osmanağaoğlu, Y. (2007). Uşak ili son sınıf öğrencilerinin çocuk haklarına ilişkin görüşleri (Yayınlanmamış yüksek lisans tezi). Ankara Üniversitesi, Ankara.

Strauss, A., \& Corbin, J. (1990). Basic of qualitative research: grounded theory procedures and techniques. Newbury Park and London: Sage.

Schempp, P., Tan, S., Manross, D., \& Fincher, M. (1998). Differences in novice and competent teachers' knowledge. Teachers and Teaching: Theory and Practice, 4(1), 9-20.

Shumba, A. (2003). Children's rights in schools: what do teachers know? Child Abuse Review, 12, 251-260.

Torun, F., \& Duran, H. (2014). Çocuk hakları öğretiminde oyun yönteminin başarıya, kalıcılığa ve tutuma etkisi. Adıyaman Üniversitesi Sosyal Bilimler Enstitüsü Dergisi, 7(16), 419-448.

Tozduman Yaralı, K., \& Güngör Aytar, F. A. (2017). Okul öncesi sınıflarında çocuğun katılım hakkının çocukların ve öğretmenlerin görüşlerine göre incelenmesi. Bartin Universitesi Eğitim Fakültesi Dergisi, 6(1), 29-47 Retrieved from http://dergipark.gov.tr/ download/article-file/230075

Uçuş, Ş. (2013). Çocuk hakları eğitimi programının hazırlanması ve değerlendirilmesi (Yayımlanmamış doktora tezi). Hacettepe Üniversitesi, Ankara

Yin, R. K. (2009). Case study research: design and methods (4th ed.). Los Angeles, Calif: Sage Publications.

Yurtsever Kılıçgün, M., \& Oktay, A. (2011). Çocuk haklarına yönelik ebeveyn tutum ölçeği'nin geliştirilmesi ve standardizasyonu. Dokuz Eylül Üniversitesi Buca Eğitim Fakültesi Dergisi, 31, 1-22

Yurtsever Kılıçgün, M. (2015). Çocuk haklarına yönelik ebeveyn tutumları ile ebeveynlik rolleri arasında ilişki. Hacettepe University Faculty of Health Sciences Journal, 1(2), 511-522 